\title{
PENGARUH METODE PEMBELAJARAN EKLEKTIK TERHADAP HASIL BELAJAR BAHASA ARAB SISWA
}

\author{
Raswan \\ Universitas Islam Negeri Syarif Hidayatullah Jakarta, Indonesia \\ raswan@uinjk.t.ac.id
}

\begin{abstract}
This research is aimed to know the effect of learning method's towards Arabic Achievement of the Fifth Grade Students of Islamic Elementary School Pembangunan Islamic State University Sharif Hidayatullah Jakarta 2009/2010. The research questions were: is there any difference in Arabic learning achievement as a whole between a group of students who have been given intiqâiyyah methods and another group of students who have been given conventional methods. This research was an experimental study using randomized control group design. The influencing factorial variable are learning methods on Arabic. The Arabic learning achievement was used to know the students' skill or capability Arabic learning. In experimental class, intiqâiyyah methods as experiment methods, and conventional methods as control methods. This research concluded that there was any difference between students Arabic achievements of group of students who have been given intiqaiyyah methods and group of students who have been given conventional methods.
\end{abstract}

Keywords: $\quad$ eclectic method, conventional method, Arabic learning achievement

\begin{abstract}
Abstrak
Penelitian ini bertujuan untuk mengetahui pengaruh metode pembelajaran terhadap Prestasi Bahasa Arab Siswa Kelas V SD MI Pembangunan UIN Syarif Hidayatullah Jakarta tahun pelajaran 2009/2010. Pertanyaan dalam penelitian ini adalah: apakah ada perbedaan prestasi belajar bahasa Arab secara keseluruhan antara sekelompok siswa yang telah diberi metode intiqâiyyah/eklektik dan kelompok siswa lain yang telah diberikan metode konvensional. Penelitian ini merupakan penelitian eksperimental menggunakan rancangan kelompok kontrol acak. Variabel faktorial yang mempengaruhi adalah metode pembelajaran pada bahasa Arab. Hasil belajar bahasa Arab digunakan untuk mengetahui keterampilan atau kemampuan pembelajaran Bahasa Arab siswa. Pada kelas eksperimen, metode intiqâiyyah sebagai metode eksperimen, dan metode konvensional sebagai metode kontrol. Penelitian ini menyimpulkan bahwa ada perbedaan prestasi antara siswa bahasa Arab kelompok siswa yang telah diberikan metode intiqâiyyah dan kelompok siswa yang telah diberikan metode konvensional.
\end{abstract}

Kata Kunci: metode eklektik, metode konvensional, hasil belajar bahasa Arab 
Arabiyât Jurnal Pendidikan Bahasa Arab dan Kebahasaaraban, 5 (1), 2018

\section{Pendahuluan}

Pembelajaran bahasa Arab di Madrasah Pembangunan belum menggembirakan. Bahasa Arab masih merupakan materi yang menjadi momok bagi sebagian siswa. Hasil belajar siswa berada pada posisi urutan terbawah dibandingkan dengan pelajaran-pelajaran lainnya. Pada tahun ajaran 2008/2009, rerata hasil Evaluasi Hasil Belajar (EHB) siswa yang diambil secara random pada kelas V saja, untuk bahasa Arab 55.9. Adapun materi lainnya berada di atasnya; Qur'an Hadits 83.5, Aqidah Akhlak 77.9, Fiqh 66.7, Sejarah Kebudayaan Islam 71.5, PKN 85.8, Bahasa Indonesia 72.6, Matematika 64.1, IPA 68.3, IPS 73.3, KTS 82.4, PENJAS 77.7, Bahasa Inggris 64.9 dan Komputer 85.1, ini merupakan kenyataan bahwa pembelajaran bahasa Arab masih perlu dicarikan solusi alternatif. ${ }^{1}$

Data menyebutkan bahwa rerata Hasil Belajar Bahasa Arab tiga tahun terakhir dapat dilihat pada tabel berikut ini':

\section{Tabel 1. Hasil Murni Belajar Bahasa Arab Siswa MI Pembangunan UIN Syarif Hidayatullah Jakarta 2006/2007-2008/2009}

\begin{tabular}{|c|c|c|c|}
\hline No & Tahun Ajaran & Rata-rata Nilai Bahasa Arab & KKM \\
\hline 1. & $2006 / 2007$ & 56.6 & 65.0 \\
\hline 2. & $2007 / 2008$ & 54.7 & 65.0 \\
\hline 3. & $2008 / 2009$ & 55.9 & 65.0 \\
\hline \multicolumn{2}{|c|}{ Rata-Rata } & 55.73 & 65.0 \\
\hline
\end{tabular}

Masalah tersebut menarik karena Madrasah Pembangunan adalah madrasah nomor satu di Indonesia sebagai madrasah unggul. Pada tahun 2004 menjadi Madrasah Berpretasi Terbaik II Tingkat Nasional dan Pada tahun 2005 menjadi Madrasah Berpretasi Terbaik I Tingkat Nasional. Nilai Ebtanas Murni (NEM) MI Pembangunan memiliki rerata terbesar se-DKI Jakarta ditingkat MIN dan MIS pada tahun pelajaran 1987/1988 s/d 2000/2001. ${ }^{3}$

Dengan keberadaan Madrasah Ibtidaiyyah (MI) Madrasah Pembangunan sebagai Madrasah Unggul bahkan dijadikan teladan oleh yang lainnya, maka diasumsikan Pembelajaran Bahasa Arabnya pun merupakan pionir bagi madrasah lainnya. Pembelajaran Bahasa Arab menjadi model pembelajaran di Madrasah Ibtidaiyyah lainnya di Indonesia.

Jika Madrasah Pembangunan saja masih kurang berhasil dalam pembelajaran bahasa Arab, apalagi madrasah lainnya. Sebagai contoh, di lingkungan KKM Kebayoran lama, Madrasah Pembangunan selalu paling tinggi dalam rerata murni nilai US-nya khusus bahasa Arab. Padahal dibandingkan dengan materi lain di MI Madrasah Pembangunan, bahasa Arab adalah materi yang belum mencapai hasil yang betul-betul menggembirakan dan selalu berada pada level bawah.

\footnotetext{
${ }^{1}$ Daya Serap EHB Madrasah Pembangunan UIN Syarif Hidayatullah Jakarta.

2 Daya Serap EHB Madrasah Pembangunan UIN Syarif Hidayatullah Jakarta.

3 Prestasi Madrasah Ibtidaiyyah Pembangunan. http://www.mpuin-jkt.sch.id/ content Lview/19/69/1/1/, diunduh Sabtu 17 Oktober 2009.
} 
Selain itu, Madrasah Pembangunan UIN Jakarta juga merupakan sekolah yang memiliki ciri khas bahasa selain sains dan akhlak mulia. Bahasa Arab merupakan bahasa yang betul-betul ditekankan untuk dikuasai oleh seluruh siswa, sebagai trademark. Karena dengan trademark itu Madrasah Pembangunan membuat dirinya berciri khas. Ketika trademark telah berhasil maka sudah sempurnalah kualitas yang diharapkan oleh konsumen Madrasah ini. Jajaran manajemen dan pimpinan juga meyakini bahwa bahasa Arab adalah bahasa yang menjadi kekuatan madrasah, karena sains harus didukung oleh akhlak mulia, akhlak mulia itu juga tidak mungkin bisa dikuatkan pada siswa, jika bahasa Arab juga tidak dimiliki oleh siswa. Karena kebanyakan buku-buku tentang agama Islam berbahasa Arab.

Ada banyak indikasi yang menyebabkan kenapa bahasa Arab di Madrasah saat ini masih berada pada level terbawah dibandingkan dengan materi pelajaran lainnya. Ada paradigma bahwa bahasa Arab kurang penting, karena saat ini, bahasa yang dipakai dalam percaturan dunia nomor satunya adalah bahasa Inggris. Para orang tua, sebagiannya menganggap, bahwa materi bahasa Arab tidak terlalu penting, sehingga dukungan mereka akan anak-anaknya kurang dibandingkan dengan materi lainnya.

Sebagai contoh, bahasa Inggris, dulu mungkin dianggap materi yang susah, namun saat ini asumsi itu sudah hilang. Orang menganggap anak usia SD/MI bisa waswes-wos bahasa Inggris bukan suatu hal yang luar biasa, biasa-biasa saja. Itu disebabkan perhatian dan dukungan keluarga atau orang tua sangat kuat.

Kebijakan pemerintah pun ikut mendukung, materi seperti matematika, hampir merupakan materi yang dianggap paling susah oleh sebagian siswa, namun dengan adanya kebijakan pemerintah yang menjadikan matematika sebagai materi yang diujinasionalkan (UN) maka matematika menjadi materi yang sangat diperhatikan oleh orang tua/wali murid. Termasuk kebijakan madrasah yang cenderung memberikan perhatian dengan mendirikan bimbingan tiga materi yang di UN-kan termasuk di dalamnya matematika.

Metode pembelajaran yang kurang improvisasi pun akan menentukan kurangnya hasil belajar bahasa Arab. Jika guru mengajar siswa hanya dengan metode yang cenderung kurang memberikan siswa aktif atau cenderung menjenuhkan maka sudah barang tentu hasilnya pun akan jauh dari harapan. Dengan demikian perlu ada alternatif metode pembelajaran yang tidak monoton sehingga semua target pembelajaran dapat dicapai dengan optimal.

Selain masalah-maslah diatas, guru, jenis tes yang digunakan, media, sarana prasaran dan lingkungan pun ikut menentukan terwujudnya keberhasilan pembelajaran bahasa Arab. Jika kesemua pendukung hasil belajar bahasa Arab tidak memadai, maka sudah bisa dipastikan bahwa pencapaian hasil akan diprediksi kurang baik.

Kesulitan pembelajaran bahasa Arab pun terjadi tidak hanya di Madrasah Pembangunan, namun di hampir semua level pendidikan yang memasukkan bahasa Arab sebagai bagian dari kurikulumnya. Di UIN saja terutama jurusan-jurusan yang non-agama, rerata peserta didik menganggap bahwa bahasa Arab itu susah dan 
menjelimet lebih parahnya lagi ada yang merasa ketakutan untuk menghadpi kuliah bahasa Arab.

Begitu juga di luar negeri, sebagai contoh sebagaimana penelitian yang dilakukan di Mesir pada tahun 1977, oleh Fathî Alî Yûnus (1936-sekarang), hampir seluruh responden penelitian menyatakan bahwa bahasa Arab susah dan ketika ditanyakan alasannya mereka menjawab "banyak orang berpendapat demikian; masyarakat sudah terlanjur meyakini bahwa bahasa Arab itu sulit dipelajari meski sudah dilakukan puluhan tahun"4. Perlu kita ingat juga bahwa, Mesir adalah negara yang bahasa hariannya Arab, sekalipun demikian, di negara ini bahasa Arab dianggap sulit, bagaimana dengan negara yang tidak menjadikan bahasa Arab sebagai bahasa harian seperti Indonesia.

Penelitian lainnya dilakukan di Malaysia, oleh Jamsurî Muhammad Syamsuddîn dan Mahdî Mas'ûd terhadap 30 Peserta didik ilmu politik (Humaniora) pada International Islamic University Malaysia menyimpulkan bahwa bahasa Arab itu sulit. Penyebab bahasa Arab itu sulit, 100\% jawaban akibat tidak minat, 87\% tidak memiliki latar belakang belajar bahasa Arab, 83\% kurikulum perguruan tinggi, 57\% kesulitan memahami materi bahasa Arab, 50\% lingkungan kelas yang tidak kondusif, 80\% karena faktor psikologis, 77\% memiliki kesan negatif terhadap bahasa Arab, 33\% herregristrasi mata kuliah bahasa Arab mempengaruhi belajar mereka di kampus ${ }^{5}$. Ini menandakan bahwa belajar bahasa Arab sampai saat ini di negeri yang notabene kental dengan Islam sekalipun, pembelajaran bahasa Arab masih sangat memperihatinkan.

Sementara itu, Bahasa Arab sendiri merupakan mata pelajaran yang diarahkan untuk mendorong, membimbing, mengembangkan dan membina kemampuan serta menumbuhkan sikap positif terhasap bahasa Arab, baik reseptif maupun produktif. Kemampuan reseptif yaitu kemampuan untuk memahami pembicaraan orang lain dan memahami bacaan. Kemampuan produktif yaitu kemampuan menggunakan bahasa sebagai alat komunikasi baik secara lisan maupun secara tertulis. Kemampuan berbahasa Arab serta sikap positif terhadap bahasa Arab tersebut sangat penting dalam membantu memahami sumber ajaran Islam yaitu al-Qur'an dan al- hadits, serta kitabkitab berbahasa Arab yang berkenaan dengan Islam bagi peserta didik.

Untuk itu, bahasa Arab di Madrasah Ibtidaiyah dipersiapkan agar pencapaian kompetensi dasar berbahasa, yang mencakup empat keterampilan berbahasa yang diajarkan secara integral, yaitu menyimak, berbicara, membaca, dan menulis. Meskipun begitu, pada tingkat pendidikan dasar (SD/MI) dititikberatkan pada kecakapan menyimak dan berbicara sebagai landasan berbahasa. Pada tingkat pendidikan menengah (SMP/MTs), keempat kecakapan berbahasa diajarkan secara seimbang. Pada tingkat pendidikan lanjut (SMA/MA), dikonsentrasikan pada kecakapan membaca dan menulis, sehingga peserta didik diharapkan mampu mengakses berbagai referensi berbahasa Arab. Jadi sebetulnya inti dari belajar bahasa Arab di Indonesia,

${ }^{4}$ Muhbib Abdul Wahab, Metode Penelitian dan Pembelajaran Nabwu: Studi Teori Linguistik Tammam Hassan, (Jakarta: PPs UIN Syarif Hidayatullah Jakarta, 2008), 1.

${ }^{5}$ Muhbib Abdul Wahab, Metode Penelitian dan Pembelajaran Nabwu: Studi Teori Linguistik Tammam Hassan. 1. 
tidak lebih dari untuk bisa memahami teks-teks keislaman yang mayoritas menggunakan bahasa Arab sebagai bahasa pengantar. Termasuk al-Qur'an dan alHadits yang keseluruhannya menggunakan bahasa Arab.

Pembelajaran bahasa Arab di Madrasah Ibtidaiyah memiliki tujuan: Pertama, Mengembangkan kemampuan berkomunikasi dalam bahasa Arab, baik lisan maupun tulis yang mencakup empat kecakapan berbahasa, yakni menyimak (istima), berbicara (kalam), membaca (qira'ah), dan menulis (kitabah). Kedua, Menumbuhkan kesadaran tentang pentingnya bahasa Arab sebagai salah satu bahasa asing untuk menjadi alat utama belajar, khususnya dalam mengkaji sumber-sumber ajaran Islam. Ketiga, Mengembangkan pemahaman tentang saling keterkaitan antara bahasa dan budaya serta memperluas cakrawala budaya. Dengan demikian, peserta didik diharapkan memiliki wawasan lintas budaya dan melibatkan diri dalam keragaman budaya. ${ }^{6}$

Untuk mencapai target pembelajaran yang diharapkan, harus didukung oleh berbagai faktor sehingga pembelajaran bahasa Arab akan memberhasilkan dan menyenangkan. Di antara faktor-faktor yang menyebabkan keberhasilan pembelajaran termasuk pembelajaran bahasa Arab adalah Guru, Bahan Ajar, Media, Sarana prasarana, lingkungan belajar, motivasi siswa, jenis evaluasi yang digunakan dan lain sebagainya.

Dari paparan diatas penulis telah meneliti hasil belajar bahasa Arab tersebut, ditinjau dari aspek metode pembelajaran yang digunakan terhadap belajar bahasa Arab siswa MI Madrasah Pembangunan UIN Syarif Hidayatullah Jakarta pada semester ganjil tahun ajaran 2009/2010. Permasalahan penelitian yang aka dijawab adalah "Apakah terdapat perbedaan hasil belajar bahasa Arab antara siswa yang diperlakukan dengan menggunakan metode intiqâiyyah dengan yang menggunakan metode konvensional? Hipotesisnya "Hasil belajar bahasa Arab siswa yang dibelajarkan dengan metode intiqâiyyah lebih tinggi daripada siswa yang diberi metode konvensional".

\section{Hasil Belajar Bahasa Arab}

Belajar merupakan suatu hal yang kompleks, karena definisi atau pengertian yang dikemukakan oleh seseorang tergantung pada teori yang dianutnya. Belajar merupakan salah satu unsur penting dalam kegiatan pendidikan. Berhasil atau gagalnya pencapaian tujuan pendidikan sangat bergantung pada proses belajar yang dialami siswa baik ketika berada di sekolah maupun di luar lingkungan sekolah.

Ada beberapa definisi belajar di antara disampaikan oleh Witherington, dalam buku Educational Psychologi seperti yang dikutip oleh Abdul Rahman Shaleh dan Muhbib Abdul Wahab dikemukakan bahwa belajar adalah suatu perubahan didalam

6 Peraturan Menteri Agama Republik Indonesia Nomor 2 Tahun 2008 tentang Standar Kompetensi Lulusan dan Standar Isi Pendidikan Agama Islam dan Bahasa Arab di Madrasah. Lembaran Negara Republik Indonesia Tahun 2008. Bab VI: Standar Kompetensi (SK) dan Kompetensi Dasar (KD) Mata Pelajaran Pendidikan Agama Islam dan Bahasa Arab Madrasah Ibtidaiyah. 
kepribadian yang menyatakan diri sebagai suatu pola baru daripada reaksi yang berupa kecakapan, sikap, kebiasaan, kepandaian, atau suatu pengertian. ${ }^{7}$

Begitu juga Gagne dalam Ibrahim menyebutkan bahwa belajar sebagai suatu perubahan dalam disposisi atau kapabilitas manusia. Perubahan dalam menunjukan kinerja (perilaku), berarti belajar itu menentukan semua keterampilan, pengetahuan, sikap dan nilai yang diperoleh individu (siswa). Dalam belajar dihasilkan berbagai macam tingkah laku yang berlainan, seperti pengetahuan, sikap, keterampilan, kemampuan, informasi dan nilai. Berbagai macam tingkah laku yang berlainan inilah yang disebut kapabilitas sebagai hasil belajar. ${ }^{8}$ Kapabilitas atau kemampuan yang diperoleh dari proses belajar tersebut dapat dikategorikan dalam lima macam, yaitu : (1) Informasi Verbal, (2) Keterampilan Intelektual, (3) Strategi Kognitif, (4) Sikap dan (5) Keterampilan Motorik. 'Begitu pula, Menurut Wortman, Loftus, dan Marshall, dalam Rivai belajar merupakan kegiatan mental individu yang kompleks dan biasanya menghasilkan perubahan tingkah laku dan pola pikir belajar, sehingga dengan adanya perubahan maka dapat dikatakan bahwa kegiatan belajar (learning) telah terjadi. ${ }^{10}$

Dari definisi belajar di atas dapat ditarik kesimpulan bahwa belajar pada intinya adalah perubahan perilaku, menciptkan sesuatu menjadi berubah. Yang dirubah adalah sikap dan tingkahlaku seseorang. Jadi jika telah terjadi perubahan perilaku maka telah terjadilah suatu proses belajar itu. Perubahan tingkah laku siswa setelah mengikuti proses pembelajaran (perubahan) berbentuk kompetensi baik kognitif, afektif, maupun psikomotorik.

Hasil adalah sesuatu yang diadakan, dibuat, dijadikan dan sebagainya oleh usaha, pikiran, dan lain-lain. ${ }^{11}$ Hasil belajar Bahasa Arab merupakan suatu kemampuan yang dicapai oleh seseorang atau individu dalam mata pelajaran bahasa Arab, setelah melalui proses belajar. Selanjutnya hasil pengukuran akan diberikan oleh guru dalam bentuk nilai. Nilai tersebut merupakan perolehan dari apa yang telah diusahakan oleh siswa, yakni belajar selama periode tertentu.

Hasil belajar yang ditunjukan dalam bentuk nilai merupakan gambaran dari penguasaan siswa terhadap pengetahuan dan keterampilan terhadap mata pelajaran. Dalam mempelajari bahasa Arab diperlukan penguasaan terhadap keterampilan Bahasa Arab, yakni menyimak, berbicara, membaca dan menulis.

Hasil belajar adalah perubahan tingkah laku siswa setelah mengikuti proses pembelajaran (perubahan) yang berbentuk kompetensi baik kognitif, afektif, maupun psikomotorik. Dan bahasa Arab adalah Bahasa Semitik Fusha yang digunakan oleh

7 Abdul Rahman Shaleh dan Muhbib Abdul Wahab, Psikologi Suatu Pengantar Dalam Persfektif Islam, (Jakarta: Kencana, 2004), 210.

${ }^{8}$ Nurdin Ibrahim, "Hasil Belajar Siswa SLTP Terbuka Tanjung Sari Sumedang Jawa Barat", Jurnal Pendidikan dan Kebudayaan, No.031 Tahun ke-7 September, 2001, 487

9 Tengku Zahara Djaafar, Kontribusi Strategi Pembelajaran Terbadap Hasil Belajar, (Fakultas Ilmu Pendidikan Universitas Negeri Padang, 2001), 82.

${ }^{10}$ Veithzal Rivai, "Prestasi Hasil Belajar Peserta Program MM Untuk Mata Kuliah Manajemen Keuangan". Jurnal Pendidikan dan Kebudayaan, No. 038 tahun ke-8 September, 2002, 728.

${ }^{11}$ Budiono, Kamus Lengkap Bahasa Indonesia, (Surabaya: Karya Agung, 2005), 183. 
Negara Timur Tengah dan Afrika Utara sebagai bahasa tulisan dan bahasa resmi. Dan meteri bahasa Arab di sini adalah Materi Bahasa Arab kelas V yang meliputi materi هذا/هذه + ال + اسم + اسم في الحديقة + الألوان dengan menggunakan pola kalimat صفة dan meliputi empat kemahiran bahasa istimâ' (menyimak), kalâm (berbicara), qirâ'ah (membaca), dan kitâbah (menulis) yang diperoleh dari kurikulum.

Dari paparan di atas dapat disimpulkan bahwa hasil belajar bahasa Arab adalah penguasaan kompetensi bahasa Arab kelas $\mathrm{V}$ yang meliputi menyimak, berbicara, membaca dan menulis bahasa Arab tentang diantaranya في الحديثقة + الألوان dengan menggunakan pola kalimat هذا/هذه + ال + اسم + اسم صفة . kemudian diskor menjadi dinilai dengan menggunakan skala 1-100.

\section{Metode Pembelajaran Bahasa Arab}

Sanjaya menyampaikan bahwa metode adalah upaya yang dilakukan untuk mengimplementasikan rencana yang sudah disusun dalam kegiatan nyata agar tujuan yang telah disusun tercapai secara optimal, ia merupakan implementasi dari strategi. Dengan bahasa lain jika strategi a plan of operation achieving maka metode merupakan $a$ way in achieving something artinya tatkala strategi merupakan perencanaan untuk mencapai sesuatu maka metode merupakan cara untuk melaksanakan strategi tersebut. Satu strategi bisa menggunakan banyak ragam metode ${ }^{12}$. Menurut Baradja, metode pembelajaran dapat diartikan sebagai cara yang digunakan untuk mengimplementasikan rencana yang sudah disusun dalam bentuk kegiatan nyata dan praktis untuk mencapai tujuan pembelajaran. Begitu juga, Anthony dalam Baradja MF mendefinisikan metode sebagai suatu rencana keseluruhan untuk mengajarkan materi bahasa secara teratur. ${ }^{13}$

Selain pengertian di atas, Parera menyatakan bahwa metode adalah suatu rancangan Selanjutnya metode pembelajaran dijabarkan ke dalam teknik dan gaya pembelajaran. Dengan demikian, teknik pembelajaran dapat diartikan sebagai cara yang dilakukan seseorang dalam mengimplementasikan suatu metode secara spesifik. Misalkan, penggunaan metode ceramah pada kelas dengan jumlah siswa yang relatif banyak membutuhkan teknik tersendiri, yang tentunya secara teknis akan berbeda dengan penggunaan metode ceramah pada kelas yang jumlah siswanya terbatas. Demikian pula, dengan penggunaan metode diskusi, perlu digunakan teknik yang berbeda pada kelas yang siswanya tergolong aktif dengan kelas yang siswanya tergolong pasif. Dalam hal ini, guru pun dapat berganti-ganti teknik meskipun dalam koridor metode yang sama ${ }^{14}$.

Jadi metode pembelajaran adalah kerangka rancangan secara keseluruhan untuk melakukan suatu aksi. Berdasarkan pendekatan yang dianut sebelum dilaksanakan dalam teknik pembelajaran secara teknis. Terdapat beberapa metode pembelajaran yang dapat digunakan untuk mengimplementasikan strategi

12 Wina Sanjaya, Strategi Pembelajaran Berorientasi Standar Proses Pendidikan, 126-127.

13 M.F. Baradja, Kapita Selekta Pengajaran Bahasa, (Malang : Penerbit IKIP Malang, 1990), 43.

${ }^{14}$ Jos Daniel Parera, Linguistik Edukasional, (Jakarta; Erlangga, 1987), 18-19. 
pembelajaran secara umum, untuk semua materi pembelajaran. Diantara jenis metode tersebut: (1) ceramah; (2) demonstrasi; (3) diskusi; (4) simulasi; (5) laboratorium; (6) pengalaman lapangan; (7) brainstorming; (8) debat, (9) simposium, dan sebagainya. ${ }^{15}$

Sedangkan mengenai jenis metode pembelajaran bahasa, Parera menyebutkan 15 macam metode; yaitu Direct Method, Natural Method, Psychological Method, Phonetic Method, Reading Method, Grammar Method, Translation Method, Grammar translation Method, Eclectic Method, Language Control Method, Mim-mem Method, Practice-theory Method, Cognate Method, dan Dual Language Method. ${ }^{16}$

Dari paparan di atas dapat disimpulkan bahwa, jenis metode pembelajaran bahasa Arab ada dua; metode umum seperti metode-metode yang digunakan dalam semua materi pembelajaran dan metode khusus, yang hanya digunakan pada pembelajaran bahasa Arab. Di antara metode tersebut adalah; metode Qawâ'id dan Terjemah (طريقة القواعد والترجمة), metode langsung (الطريقة المباشرة), metode Audiolingual ( الطريقة) (السمعية الشفوية), dan metode eklektik (الطريقة الانتقائية). Untuk metode terakhir akan dijelaskan seperti berikut. $^{17}$

\section{Metode Intiqâiiyyah (Eklektik)}

Metode intiqâiyyah (eklektik), yaitu metode gabungan yang mengambil aspekaspek positifnya baik dari keterampilan maupun pengetahuan bahasa, sehingga mencapai tujuan dan hasil pembelajaran yang maksimal. Metode eklektik dimaksud mencakup metode percakapan, membaca, latihan, dan tugas. ${ }^{18}$

Metode eklektik adalah metode yang hadir karena ketidakpuasan atas metode pembelajaran bahasa asing yang sudah ada; metode Qawâid dan Terjemah, metode langsung dan metode sam'iyyah syafawiyyah. Metode ini didefinisikan sebagai metode yang mengambil aspek-aspek yang tepat dalam metode sebelumnya. ${ }^{19}$

Metode dalam pengajaran bahasa Arab secara garis besar ada empat: yaitu metode Qawẩid dan Terjemah (طريقة القواعد والترجمة), metode langsung (الطريقة المباشرة), metode Audiolingual (الطريقة السمعية الشفوية), dan metode eklektik (الطريقة الانتقائية).

Al-'Anati mengemukakan definisi metode eklektik sebagai:

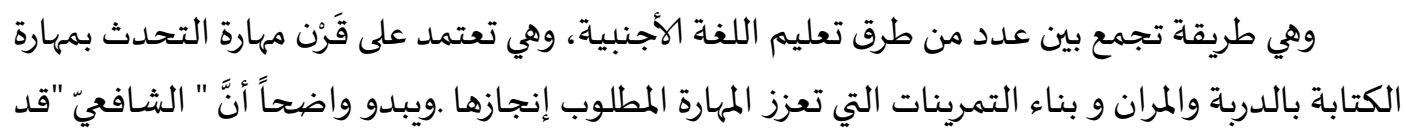

15 Baradja, M.F. Kapita Selekta Pengajaran Bahasa, 43.

${ }^{16}$ Jos Daniel Parera. Linguistik. Edukasional... hal. 18-19.

${ }^{17}$ Syamsul Hadi. Glosarium Kata dan Istilah Asing dalam Bahasa Arab. (Yogyakarta: Seksi Penerbitan Jurusan Sastra Asia Barat FIB UGM, 2005), 13-16. Lihat juga Mamduh Muhammad Khasarah, 'Ilm alMushthalabât wa Tharâiq Wadh al-Musthalaḅât fì al- 'A rabiyyah, 2008, Thabatul Ula, 143-145.

18 Abdul Halim Hanafi. dengan bangga didukung oleh WordPress Entri (RSS)and Komentar (RSS). Dalam http://www.abdulhalimhanafi. stainbatusangkar.ac .id/?p=6

د.س.، ص. جا. ، محمد علي الخولي، أساليب تدريس اللغة العربية، المملكة العربية السعودية: مكتبة الفرزدق، 19 


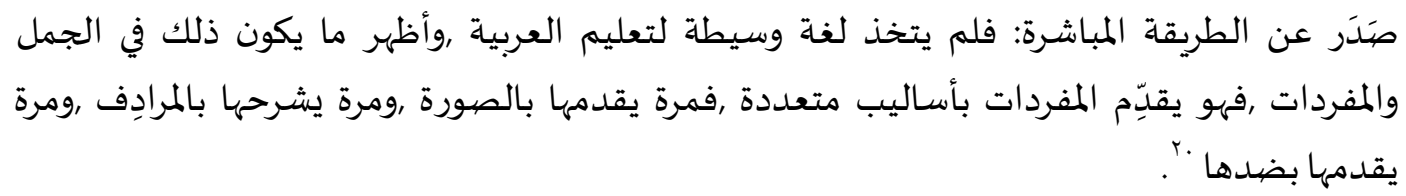

Metode eklektik artinya gabungan atau kombinasi; cara menyajikan bahan pelajaran bahasa Arab melalui macam-macam metode, sehingga proses pembelajaran lebih banyak ditekankan pada kemahiran bercakap-cakap, menulis, membaca dan memahami pengertian-pengertian tertentu. ${ }^{21}$

Sedang menurut Lundeto, metode eklektik dalam bahasa Arab, memiliki penamaan yang bervariasi, di antaranya adalah al-Tharíqah al-Intiqâ'iyyah, al-Tharíqah alMukhtârah, al-Thariqah al-Taufíqiyyah, al-Tharîah al-Izdiwaijiyyah, dan al-Tharîah alTaulifiyyah. Hadirnya beberapa nama ini bukannya tanpa alasan. Keberagaman nama itu lahir karena metode ini hendak menggabungkan dan memilih aspek-aspek positif dari berbagai metode dan mengadopsinya. ${ }^{22}$ Lundeto mendefinisikan bahwa metode eklektik adalah metode yang menggabungkan dan memilih aspek-aspek positif dari berbagai metode dan mengadopsinya.

Paparan di atas dapat disimpulkan bahwa yang dimaksud dengan metode eklektik adalah metode yang menggabungkan metode terjemah dan kaidah, metode langsung dan metode mendengar dan mengucapkan menjadi bagian yang tidak akan terpisahkan karena bahasa Arab tidak akan terlepas dari empat kemahiran bahasa; menyimak (istimâ), berbicara (kalâm), membaca (qirâ'ab), dan menulis (kitâbah), dan tanpa metode eklektik tidak mungkin semua kemahiran bahasa akan dikuasai oleh siswa.

\section{Rancangan Metode Intiqâiiyyah (Eklektik)}

\section{Materi Ajar Bahasa Arab}

Jika kita amati suatu materi ajar bahasa terdiri atas (1) topik materi ajar dan (2) desainnya yang menggambarkan kegiatan pembelajarannya. Topik materi ajar bahasa Arab yang efektif adalah topik-topik yang komunikatif dan kontekstual tentang tema keseharian, keagamaan, iptek, dan kepribadian. ${ }^{23}$

\section{Desain Pembelajarannya}

Desain pembelajaran bahasa Arab terdiri dari ${ }^{24}$ :

(1) Keterampilan Mendengar dan Berbicara (Istimâ'-Kalâm)

${ }^{20}$ Walîd al-'Anâtî, Kitâb "Nûn wa al-Qalam” Dirâsah Lisâniyah Tarbawiyyah li Ta'lìm al-'Arabiyyah li al-Nâthiqîn bi Ghairihâ. (Jâmi’ah al-Batra, al-Urdun, 1430 H/2009 M).

${ }^{21}$ Ayatullah, "Penerapan Metode Eklektik pada Pembelajaran Bahasa Arab Siswa Kelas VI SDIT Anak Sholeh Mataram", Jurnal Palapa, Vol. 4 No. 1, 2016, 149-167. Lihat juga Anwar Abd. Rahman, "Pengajaran Bahasa Arab dengan Metode Eklektik", Jurnal Adabiyah, Vol. 11 No. 1, 2011, 65-74.

22 Adri Lundeto, "Pengembangan Metode Pengajaran Bahasa Arab", ttp://jurnaliqro.files. wordpress .com/2008/08/04-adri-37-47.pdf. diunduh Rabu, 21 Oktober 2009.

23 Adri Lundeto, "Pengembangan Metode Pengajaran Bahasa Arab", ttp://jurnaliqro.files. wordpress .com/2008/08/04-adri-37-47.pdf. diunduh Rabu, 21 Oktober 2009.

24 Adri Lundeto, "Pengembangan Metode Pengajaran Bahasa Arab", ttp://jurnaliqro.files. wordpress .com/2008/08/04-adri-37-47.pdf. diunduh Rabu, 21 Oktober 2009. 
Arabiyât Jurnal Pendidikan Bahasa Arab dan Kebahasaaraban, 5 (1), 2018

(a) Teks Percakapan yang komunikatif dan kontekstual/atau bentuk CD

(b) Mufradât

(c) Tadrîbât (Pelatihan)

- Ajril Hiwâr kamâ fil mitsâl (Percakapkanlah sbg. contoh)

- Hawnil kamâ fil mitsâl (Rubahlah sbg. contoh)

- Istabdil kamaâ fil mitsâl (gantilah sbg. contoh)

(d) Al'ab lughawiyah (permainan bahasa)

(e) Wajizb (Tugas)

(2) Keterampilan Membaca dan Menulis (Qirâ'ah-Kitâbah)

(a) Teks bacaan yang komunikatif, pragmatik, dan kontekstual

(b) Mufradât

(c) Contoh-contoh teks yang struktural, komunikatif, dan kontekstual

(d) Penjelasan dan kesimpulan (oleh pebelajar atau pengajar)

(e) Latihan Membaca

$>$ Bacalah dengan membunyikan semua baris akhirnya

$>$ Terjemahkan teks bacaan ke dalam bahasa Indonesia standar

$>$ Buatlah kesimpulan bacaan

> Sebutkan jenis kata yang diberi garis bawah

$>$ Jelaskan terjadinya perubahan baris akhir pada kata yang diberi garis bawah

> Jelaskan i'râb kata-kata yang diberi garis bawah dan alasannya (setelah pemelajar mempelajari sejumlah materi ajar yang mengantarnya ke arah ini)

(f) Wajib (Tugas)

\section{Langkah-langkah pembelajaran}

Langkah-langkah pembelajaran dengan menggunakan metode eklektik di MI diterapkan dengan mengikuti beberapa langkah pembelajaran. Karena penelitian ini dilaksanakan pada MI Pembangunan UIN Jakarta dengan menggunakan kurikulum KTSP maka pembelajaran dipisah ke dalam empat keterampilan. Sementara keterpaduannya ada pada aspek bunyi, kosakata dan kaidah. Berikut adalah langkah pembelajaran masing-masing:

\section{Istimâ'/Menyimak:}

Langkah-langkah pembelajarannya adalah sebagai berikut:

a. Guru dan peserta didik menyanyikan lagu-lagu tentang kosakata dan kaidah yang sedang dipelajari

b. Peserta didik dibagi menjadi dua kelompok dan ditempatkan dalam 2 tempat yang terpisah

c. Pembagian kelompok bisa dilakukan dengan permainan

d. Guru membacakan dan menjelaskan teks yang diajarkan, misalnya teks yang berjudul في الحديقة+الألوان pada kelompok 1 
e. Untuk kelompok 2 guru menceritakan teks tersebut dengan bahsa guru sendiri melalui strategi ceramah.

f. Setelah selesai Peserta didik dikumpulkan dan masing-masing dari anggota kelompok 1 diminta mencari pasangan dari anggota kelompok 2.

g. Guru membagikan soal mengenai isi teks

h. Ketika mengerjakan soal bisa diselingi musik-musik Arab yang menentramkan

i. Masing-masing pasangan diminta untuk menggabungkan hasil belajar dan dapat menjawab pertanyaan-pertanyaan dari guru seputar isi teks.

j. Guru memberikan reward dan punishment berbentuk permainan menghibur

k. Guru memberikan tugas perkerjaan untuk dikerjakan di rumah

\section{Kalâm/Berbicara :}

Langkah-langkah pembelajarannya adalah sebagai berikut:

a. Guru dan peserta didik menyanyikan lagu-lagu tentang kosakata dan kaidah yang sedang dipelajari

b. Guru dan siswa mentukan topik bacaan yang akan disampaikan

c. Guru menyajikan isi bacaan dalam bentuk peta konsep kemudian menyampaikan pembelajaran melalui peta konsep dari hasil bacaan itu tanpa melihat buku

d. Guru menerangkannya perlahan-lahan, kalimat perkalimat atau paragraf per paragraf agar Peserta didik dapat mengikuti alur tema tersebut

e. Setelah satu item konsep diterangkan, guru minta peserta didik untuk mengungkapkannya kembali dengan bahasa Arab yang mereka miliki

f. Guru melanjutkan lanhkah tersebut pada item konsep selanjutnya setelah meminta peserta didik untuk mengulangnya kembali

g. Setelah semua konsep cerita terpaparkan guru memberi peserta didik kesempatan untuk mengulangi dari awal sampai akhir tanpa menghapus peta konsep yang tertulis di papan tulis agar memudahkan mereka untuk menerangkannya secara panjang lebar

h. Guru minta peserta didik untuk maju kedepan dan menuturkan topik tersebut dari awal hingga akhir

i. Guru memberi reward bagi peserta didik yang mampu menjelaskanya sampai selesai

j. Kemudian cross check alur topik yang telah dibahasakan peserta didik dengan bahasa bacaan yang ada

k. Guru memberikan pekerjaan rumah kepada siswa

\section{Qirâ'ah/Membaca}

Langkah-langkah pembelajarannya adalah sebagai berikut:

a. Guru dan peserta didik menyanyikan lagu-lagu tentang kosakata dan kaidah yang sedang dipelajari

b. Guru bersama siswa mentukan teks wacana yang akan dibaca

c. Guru meminta peserta didik untuk mempelajarinya dan beri tanda pada mufradat yang tidak dipahami dalam batas waktu yang sudah ditentukan misalnya 10-15 menit 
d. Siswa diberi kesempatan 5-10 menit untuk bertanya kepada guru

e. Guru menjawab pertanyaan siswa dengan diskusi atau menanyakan lagi (sharing) pada peserta didik lainnya.

f. Guru memberi kesempatan lagi untuk bertanya dan sharing dengan peserta didik dan seterusnya.

g. Guru memberi reward bagi yang mampu menjawab

h. Guru menjelaskan secara singkat teks wacana.

i. Guru mengakhiri pembelajaran dengan memberikan pertanyaan-pertanyaan seputar mufradat dan pemahaman peserta didik pada wacana yang di pelajari. Kegiatan ini dilaksanakan dengan permainan cepat-tepat.

j. Guru memberikan pekerjaan rumah kepada siswa

\section{Kitâbah/Menulis}

Langkah-langkah pembelajarannya adalah sebagai berikut:

a. Guru dan peserta didik menyanyikan lagu-lagu tentang kosakata dan kaidah yang sedang dipelajari

b. Guru membagikan kertas kepada peserta didik

c. Peserta didik diminta untuk menulis informasi seputar problematika kehidupan yang mereka peroleh lewat media cetak, media elektronik, ataupun lewat pengamatan meraka atas realitas kehidupan manusia.

d. Menuliskannya ke dalam bahasa Arab

e. Setiap peserta didik diminta mempresentasikan tulisannya satu persatu

f. Setelah seorang peserta didik selesai mempresentasikan, guru dan Peserta didik lainnya memberikan komentar terhadap tulisan tersebut, dan begitu seterusnya.

g. Reward diberikan kepada tulisan terbaik diantara siswa

h. Guru memberikan pekerjaan rumah ${ }^{25}$

Dapat disimpulkan bahwa yang dimaskud dengan metode eklektik adalah metode yang menggabungkan metode terjemah dan kaidah, metode langsung dan metode mendengar dan mengucapkan menjadi bagian yang tidak akan terpisahkan karena bahasa Arab tidak akan terlepas dari empat kemahiran bahasa; menyimak (istimâ), berbicara (kalâm), membaca (qiráah), dan menulis (kitâbah), dan tanpa metode eklektik tidak mungkin semua kemahiran bahasa akan daikuasai oleh siswa. Langkahlangkah pembelajaran di atas hanya salah satu yang bisa diterapkan. Guru bisa membuat metode eklektik lainnya disesuaikan dengan keterampilan bahasa yang dibelajarkan. Semakin beragam langkah-langkahnya maka akan semakin mencipatakan pembelajaran yang menarik dan pada gilirannya tujuan akan tercapai dengan maksimal. Untuk siswa MI perbanyak permainan bahasa dan ice breaking karena siswa usia MI cenderung senang dengan berbagai permainan. Pembelajaran serasa bermain bukan sebaliknya.

${ }_{25}$ Adri Lundeto. Pengembangan Metode Pengajaran Bahasa Arab. http://jurnaliqro.files. wordpress .com/2008/08/04-adri-37-47.pdf, diunduh Rabu, 21 Oktober 2009. 


\section{Metode Penelitian}

Metode penelitian yang diterapkan dalam penelitian ini adalah metode eksperimen menggunakan rancangan kelompok kontrol acak. Variabel faktorial yang mempengaruhi adalah metode pembelajaran pada bahasa Arab. Hasil belajar bahasa Arab digunakan untuk mengetahui keterampilan atau kemampuan pembelajaran Bahasa Arab siswa. Pada kelas eksperimen, metode intiqâiyyah sebagai metode eksperimen, dan metode konvensional sebagai metode kontrol di kelas kontrol. Populasinya adalah kelas 5 MI Pembangunan UIN Jakarta sebanyak 8 rombongan belajar dan sampelnya adalah dua rombongan belajar atau kelas. Satu kelas atau rombel terdiri dari 28-30 siswa dan dari setiap kelas sampel yang mengembalikan angket yang dikirimkan untuk orang tua siswa sekitar 20 siswa dari masing-mesing rombel/kelas. Ujicoba dilaksanakan selama satu semester tahun pelajaran berlangsung.

\section{Deskripsi Data}

Berdasarkan hasil identifikasi data yang telah dilakukan oleh peneliti, berikut disajikan rangkuman hasil analisisnya:

\section{Tabel 2. Komposisi Rata-rata Skor Hasil Belajar Bahasa Siswa Berdasarkan} Jenis Metode Pembelajaran

\begin{tabular}{|c|c|}
\hline \multicolumn{2}{|c|}{ Metode Pembelajaran (A) } \\
\hline Initiqaiyyah (A1) & Konvensional (A2) \\
\hline$n=20$ & $n=20^{26}$ \\
$\bar{X}=78$ & $\bar{X}=67,2$ \\
$s=10,17$ & $s=14,74$ \\
\hline
\end{tabular}

Penelitian ini menguji tentang pengaruh metode pembelajaran terhadap hasil belajar bahasa Arab siswa kelas V MI Madrasah Pembangunan UIN Syarif Hidayatullah Jakarta 2009/2010. Data dikumpulkan dengan menggunakan instrumen hasil belajar bahasa Arab siswa berupa tes bentuk objektive yang telah divalidasi. Guna memberikan gambaran umum mengenai data, maka dilakukan dengan menggunakan statistik deskriptif untuk menentukan harga maksimum, minimum, rentang, simpangan baku dan varians, dan ukuran gejala pusat seperti rerata (mean), nilai tengah (median), nilai yang sering muncul (modus) yang dirangkum dalam satu tabel.

Data disajikan dalam bentuk daftar distribusi frekuensi serta histogram. Perhitungan validitas instrumen penelitian menggunakan bantuan komputer program SPSS For Windows 15.0 dan Microsoft Excel dan reliabilitas, dan reliabilitas tes hasil belajar menggunakan rumus KR-20. sedangkan statistik inferensial digunakan dalam uji normalitas dan homogenitas.

${ }^{26}$ Jumlah sampel masing-masing sampel maknanya adalah satu kelas yang jumlahnya sekitar 2830 dimana dari 28-30 tersebut yang mengembalikan angket yang dikirim kepada orang tua hanya 20 siswa. 
Data tentang Hasil Belajar bahasa Arab Siswa yang diajar dengan menggunakan Metode Intiqâiyyah (A1)

Skor yang diperoleh sebagai berikut: skor maksimal 100 dan skor minimal 50, rentang skor adalah 50 , banyak kelas 6 , panjang kelas 9, simpangan baku 15.24, varians 232,26, reratanya 78, median 80, dan modus 80, 90 dan 100 besar skor yang hampir sama antara harga rerata, median, dan modus mengindikasikan bahwa sebaran skor hasil belajar bahasa Arab berdistribusi normal. Skor empirik Hasil Belajar bahasa Arab Siswa yang diajar dengan menggunakan Metode Intiqaiiyyah disajikan dalam tabel distribusi frekuensi, maka hasilnya pada tabel berikut:

Tabel 3. Hasil Belajar Bahasa Arab Siswa MI Madrasah Pembangunan yang diberi Metode Intiqâiyyah

\begin{tabular}{|c|c|c|c|c|}
\hline & Nilai & \multicolumn{3}{|c|}{ Frekuensi } \\
\cline { 3 - 5 } Nilai & Tengah & Absolut & Relatif (\%) & Kumulatif \\
\hline $48-56$ & 52 & 1 & 5 & 1 \\
\hline $57-65$ & 61 & 3 & 15 & 4 \\
\hline $66-74$ & 70 & 5 & 25 & 9 \\
\hline $75-83$ & 79 & 4 & 20 & 13 \\
\hline $84-92$ & 88 & 3 & 15 & 16 \\
\hline $93-101$ & 97 & 4 & 20 & 20 \\
\hline Jumlah & & 20 & 100 & \\
\hline
\end{tabular}

Dari tabel di atas, berdasarkan pengelompokan skor tersebut dari 20 responden dapat diketahui responden terbanyak memiliki skor antara 66-74.

Selanjutnya, apabila penyebaran skor variabel hasil belajar bahasa Arab ditampilkan pada histogram dan poligon, maka hasilnya sebagai berikut:

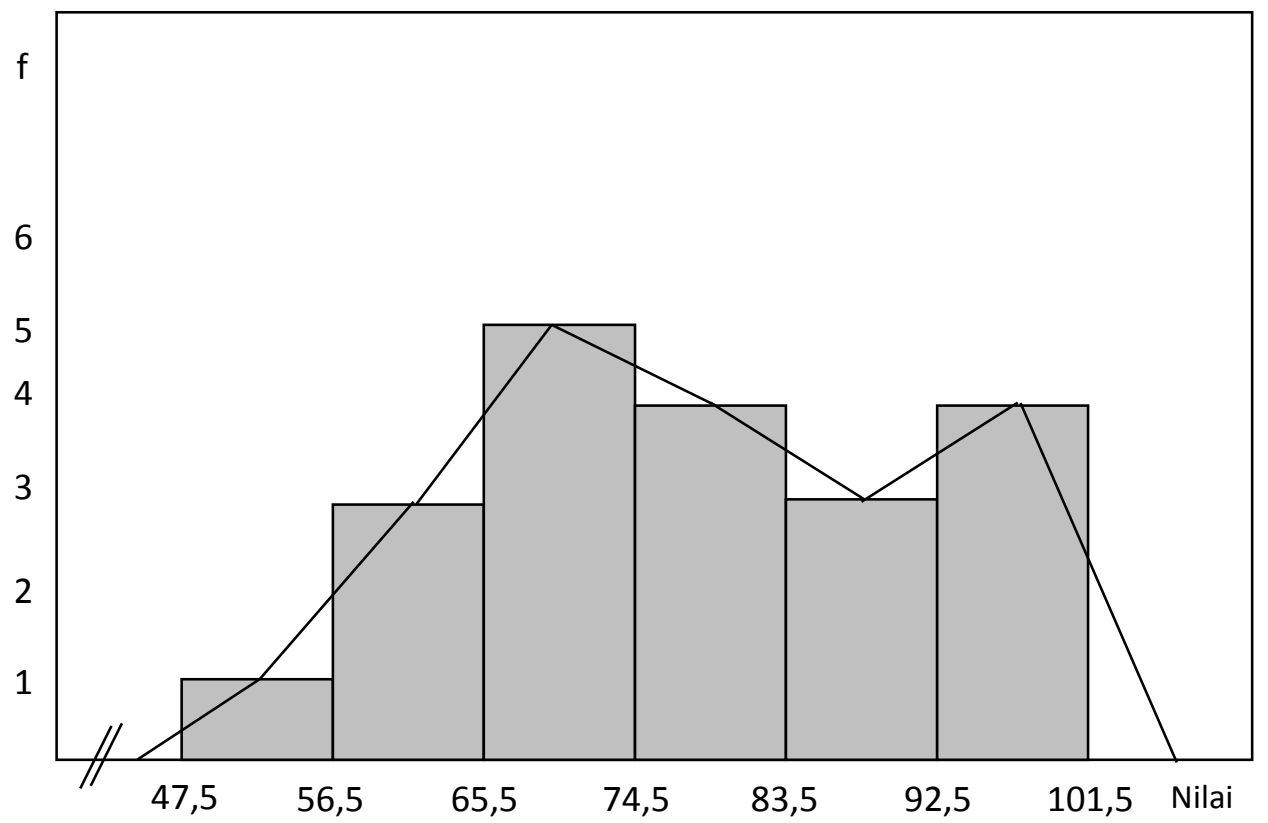

Gambar 1. Histogram dan Poligon Skor Hasil Belajar Bahasa Arab 
Kolom vertikal pada histogram menunjukan berapa kali hasil belajar bahasa Arab siswa muncul dalam kumpulan data, garis horizontal menggambarkan hasil belajar bahasa Arab siswa. Tampak kolom vertikal tertinggi berada antara 66-74. hal ini menunjukan bahwa hasil belajar bahasa Arab siswa yang paling sering muncul berada pada kisaran tersebut yaitu pada frekuensi 5.

\section{Data tentang Hasil Belajar bahasa Arab Siswa yang diajar dengan menggunakan Metode Konvensional/Qaw'id dan Terjemah (A2)}

Skor yang diperoleh sebagai berikut: skor maksimal 90 dan skor minimal 20, rentang skor adalah 70, banyak kelas 6, panjang kelas 12, simpangan baku, $\mathbf{1 7 . 3 8}$ varians 302.06, reratanya 67.2, median 70, dan modus 80 besar skor yang hampir sama antara harga rerata, median dan modus mengindikasikan bahwa sebaran skor hasil belajar bahasa Arab berdistribusi normal. Skor empirik hasil belajar bahasa Arab Siswa yang diajar dengan menggunakan Metode Intiqaiyyah disajikan dalam tabel distribusi frekuensi, maka hasilnya pada tabel berikut:

\section{Tabel 4. Hasil Belajar Bahasa Arab Siswa MI Madrasah Pembangunan yang diberi Metode Konvensional (Qawâ'id dan Terjemah)}

\begin{tabular}{|c|c|c|c|c|}
\hline & Nilai & \multicolumn{3}{|c|}{ Frekuensi } \\
\cline { 3 - 5 } Nilai & Tengah & Absolut & Relatif (\%) & Kumulatif \\
\hline $19-30$ & 24.5 & 1 & 5 & 1 \\
\hline $31-42$ & 36.5 & 1 & 5 & 2 \\
\hline $43-54$ & 48.5 & 2 & 10 & 4 \\
\hline $55-66$ & 60.5 & 4 & 20 & 8 \\
\hline $67-78$ & 72.5 & 6 & 30 & 14 \\
\hline $79-90$ & 84.5 & 6 & 30 & 20 \\
\hline Jumlah & & 20 & 100 & \\
\hline
\end{tabular}

Dari tabel di atas, meyoritas responden sokrnya berada antara 67 - 78 dan 7990 yaitu sebanyak 12 atau $60 \%$. Responden dengan skor berada di bawah rata-rata sebanyak 8 siswa atau $40 \%$ dan responden dengan skor berada di atas rerata sebanyak 12 atau 60\%. Kesimpulan bahwa hasil belajar bahasa Arab siswa kelas V Madrasah Ibtidaiyyah Pembangunan UIN Jakart yang diajar dengan metode konvensional (Qawâ'id dan Terjemah) termasuk kategori rendah

Paparan Hasil belajar bahasa Arab siswa kelas V Madrasah Ibtidaiyyah Pembangunan UIN Jakarta yang diajar dengan metode konvensional lebih diperjelas dengan dengan sajian histogram dan poligon frekuensi dalam gambar di bawah ini: 
Arabiyât Jurnal Pendidikan Bahasa Arab dan Kebahasaaraban, 5 (1), 2018

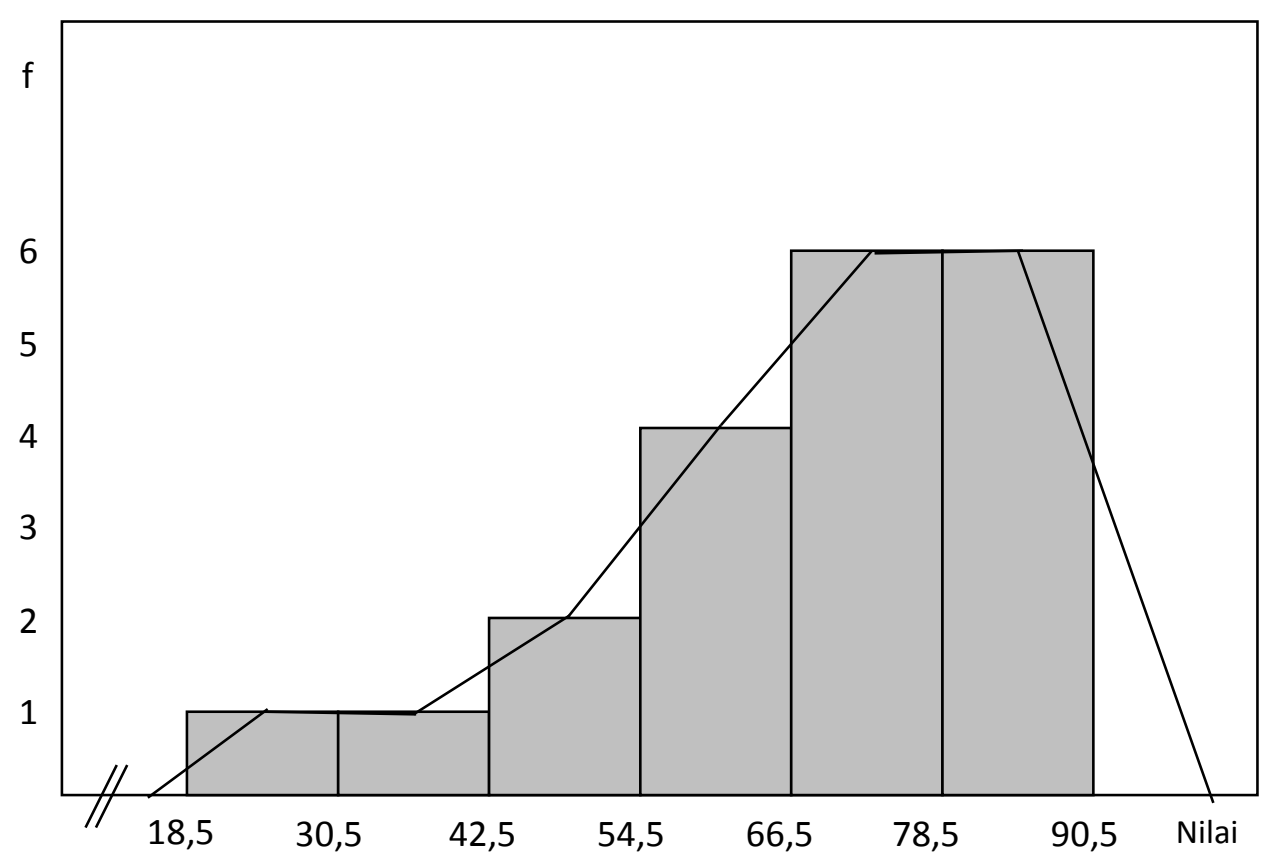

Gambar 2. Histogram dan Poligon Skor Hasil Belajar Bahasa Arab

Kolom vertikal pada histogram menunjukan berapa kali hasil belajar bahasa Arab siswa muncul dalam kumpulan data, garis horizontal menggambarkan hasil belajar matematika siswa. Tampak kolom vertikal tertinggi berada antara 67-78 dan 79-90. Hal ini menunjukan bahwa hasil belajar bahasa Arab siswa yang paling sering muncul berada pada kisaran tersebut yaitu pada frekuensi 12.

\section{Pengujian Hipotesis}

Hasil belajar bahasa Arab siswa yang diberi metode intiqâiyyah lebih tinggi daripada siswa yang diberi metode konvensional yakni metode qawâ'id dan terjemah yang diterapkan di Kelas V MI Madrasah Pembangunan, Hipotesis statistik yang dapat dibuat adalah sebagai berikut:

$$
\begin{aligned}
& H_{0}: \mu_{10}=\mu_{20} \\
& H_{1}: \mu_{10}>\mu_{20}
\end{aligned}
$$

Hasil analisis variansi menyimpulkan bahwa varians antar kolom sangat signifikan karena Fhitung $=6,82>$ Ftabel $=4,11$ pada taraf signifikansi 0,05. Berdasarkan hasil perhitungan di atas maka dapat disimpulkan bahwa hipotesis teruji kebenarannya, yaitu Hasil belajar bahasa Arab siswa yang diberi metode intiqâiyyah lebih tinggi daripada siswa yang diberi metode konvensional/ Qawâ'id dan Terjemah.

Hasil pengujian menunjukkan perbedaan, oleh karena itu dilanjutkan dengan uji Tukey sebagai uji lanjut untuk mengetahui metode mana yang lebih unggul. Perhitungan uiji Tukey menunjukkan bahwa hasil belajar bahasa Arab siswa yang diajar dengan menggunakan metode intiqaiyyah lebih tinggi dari daripada diajar dengan menggunakan metode konvensional/ Qawầid dan Terjemah dengan hasil uji lanjut 
menggunakan uji Tukey yakni $Q_{\text {hitung }}=10,47>Q_{\text {tabel }}=5,02$ pada taraf signifikansi 0,01, berarti hasil belajar bahasa Arab siswa Madrasah Ibtidaiyyah Pembangunan UIN Jakarta yang diajar dengan menggunakan metode intiqâiyyah lebih unggul daripada siswa yang diajar menggunakan metode konvensional/ Qawâid dan Terjemah.

\section{Interpretasi Hasil Penelitian}

Berdasarkan hasil perhitungan dan pengujian hipotesis menunjukkan hipotesis dapat diterima. Hasil penelitian menunjukkan bahwa: Pertama, hasil belajar bahasa Arab siswa yang diberi metode intiqâiyyah lebih tinggi daripada siswa yang diberi metode konvensional/ Qawẩid dan Terjemah. Hal tersebut disebabkan oleh karena pembelajaran dengan metode intiqâiyyah lebih mengarah kepada dinamisme pembelajaran. Pembelajaran tidak monoton, sebaliknya fleksibel dan menyenangkan bagi semua anak yang belajar bahasa Arab.

Sementara pembelajaran dengan menggunakan metode konvensional/Qawầid dan Terjemah cenderung menjenuhkan bagi rata-rata siswa. Pembelajaran menjadi kaku, stagnan, dan tidak menarik bagi siswa. Pada gilirannya hasil belajar bahasa Arab siswa lebih rendah jika dibandingkan dengan pembelajaran menggunakan metode intiqâiyyah.

Hal tersebut sebagai jawaban atas teori yang menyatakan bahwa metode intiqâiyyah adalah metode yang membebaskan guru mengikuti metode yang cocok bagi muridnya; guru berhak menggunakan kelebihan berbagai metode yang dipandang tepat oleh guru kemudian digabungkan dalam satu kegiatan pembelajaran. Sebagaimana ia berhak juga memilih teknik-teknik yang menurutnya tepat untuk kondisi pembelajaran. Ia juga menggunakan salah satu teknik metode qawâ'id dan terjemah ketika mengajarkan satu kemahiran bahasa lalu menggunakan teknik mendengar dan bicara pada kondisi lainnya. Oleh sebab-sebab: setiap metode punya kelebihan yang bermanfaat bagi pengajaran bahasa, tidak pernah ditemukan metode yang tidak ada cacatnya, setiap metode saling melengkapi, bukan bertentangan, dan tidak ada metode yang mampu sesuai dan cocok untuk semua tujuan pembelajaran, siswa, guru dan kurikulum. $^{27}$

Alasan metode ini tepat dalam pembelajaran bahasa, karena: Pertama, Setiap metode pengajaran bahasa asing memiliki kelebihan masing-masing, dan bisa kita mengambil kebaikan-kebaikannya. Kedua, Tidak ada metode yang sempurna dan tidak ada metode yang jelek, akan tetapi setiap metode pembelajaran bahasa asing ada kelebihan dan ada kekurangan dan kesemuanya memiliki alasan dan dalil masingmasing.

Ketiga, Akan lebih baik jika kita berpandangan bahwa satu metode hanya akan sempurna jika kita menyandingkannya dengan metode lain. Bukan beranggapan bahwa

27 .Baiq Tuhfatul Unsi, "Optimalisasi Pembelajaran Bahasa Arab Melalui Model Pembelajaran Komunikatif-Eklektik”, Murobbi: Jurnal Ilmu Pendidikan, Vol. 1 No. 1, 2017, 102-119. Lihat juga Ahmad Rifa'i, "Implementasi Thariqah al-Intiqaiyyah ( Metode Eklektik) Pada Pembelajaran Bahasa Arab di Mtsn Kediri 1", Jurnal Realita, Vol. 13 No. 2 Juli 2015, 162-172. 
antara satu metode dengan lainnya saling bertentangan, Keempat, Tidak pernah ditemukan ada satu metode pun yang sesuai atau cocok terhadap semua tujuan, siswa, guru, dan semua jenis kurikulum pengajaran bahasa asing.

Kelima, yang penting dalam pembelajaran adalah fokus pada kebutuhan siswa, bukan memikirkan metode apa yang digunakan. Keenam, Guru harus merasa diri bebas menentukan teknik yang tepat untuk siswanya, dan tidak canggung karena hanya memikirkan menggunakan banyak metode. Namun lebih baik jika guru memilih teknik-teknik yang tepat dan cocok bagi kebutuhan siswanya dan sesuai dengan kondisi pembelajaran dari metode-metode yang ada.

Dengan keberadaan bahwa metode intiqâiyyah adalah penyempurna bagi metode pembelajaran bahasa Arab sebelumnya termasuk metode pembelajaran qawâid dan terjemah yang dijadikan metode konvensional dalam penelitian ini. Jelas sekali kesesuaian antara teori yang peneliti temukan dalam berbagai referensi.

Oleh karenanya, metode intiqâiyyah adalah metode dalam pembelajaran bahasa Arab dengan mengkombinasikan aspek-aspek positif metode sebelumnya sekaligus sebagai jawaban atas kelemahan kelemahan metode sebelumnya diikuti dengan kontekstualisasi materi pembelajaran kepada yang lebih tepat dan memberhasilkan.

Hasil penelitian ini sesuai dengan teori yang dikemukakan oleh al-Khûlî yang menyatakan metode Intiqâiyyah hadir karena ketidakpuasan atas metode pembelajaran bahasa asing yang sudah ada; metode qawâid dan terjemah, metode langsung dan metode sam'iyyah syafawiyyah, metode yang mengambil aspek-aspek yang tepat dalam metode sebelumnya. ${ }^{28}$

\section{Simpulan}

Dari uraian tersebut dapat disimpulkan bahwa hasil belajar siswa yang menggunkan metode intiqâiyyah lebih tinggi dibandingkan siswa yang diajar dengan menggunakan metode konvensional. Peneliti memberikan saran-saran berdasarkan hasil penelitian yakni pertama, hendaknya para ahli dan pemerhati bahasa Arab, yang sampai saat ini pengembangannya sangat lemah lebih berusaha mengembangkan metode-metode pembelajaran bahasa Arab yang produktif, sehingga ada usaha-usaha nyata dan tepat sasaran dalam menyelesaikan segala problem yang selalu muncul di lapangan, kedua, hendaknya Madarsah Ibtidaiyah Pembangunan UIN Syarif Hidayatullah Jakarta, dapat menjadikan penelitian ini sebagai feedback dengan melakukan pelatiahan-pelatihan metode pembelajaran khusus bagi guru bahasa Arab untuk memperbaiki diri dengan kebijakan-kebijakan yang menunjang, karena bagi Madrasah termasuk didalamnya Madrasah Ibtidaiyah Pembangunan keberadaan bahasa Arab adalah trademark, jika bukan dengan bahasa Arab maka Madrasah bukanlah Madrasah Ibtidaiyah namun Sekolah Dasar. Dan ketiga, hendaknya guru bahasa Arab, berusaha memberikan penanggulangan-penanggulangan yang tepat sasaran khususnya jika ingin menjadikan bahasa Arab adalah bahasa yang mudah,

${ }^{28}$ Al-Khûlî, Muhammad 'Alî, Asâlîb Tadrîs al-Lughah al-'Arabiyyah, (al-Mamlakah al-Arabiyyah alSu'ûdiyyah: Maktabah al-Farzadaq, t.t). 
Arabiyât Jurnal Pendidikan Bahasa Arab dan Kebahasaaraban, 5 (1), 2018

harus dibenahi sistem dan metode pembelajarannya dengan memaksimalkan usaha memilih metode yang mampu memotivasi siswa tentang belajar bahasa Arab dan menumbuhkan rasa percaya diri siswa.

Ada beberapa saran yang perlu ditindaklanjuti pimpinan MI Madrasah Pembangunan dan madrasah serta lembaga pendidikan yang membelajarkan bahasa Arab setingkat MI lainnya agar terus memberikan dukungan dan dorongan kepada guru untuk mengikuti pendidikan dan kegiatan ilmiah lainnya terutama yang berkaitan peningkatan metode pembelajaran bahasa Arab. Guru bahasa Arab di MI Pembangunan dan madrasah serta lembaga pendidikan yang membelajarkan bahasa Arab setingkat MI lainnya agar terus meningkatkan kemampuan menerapkan metode eklektik dalam pembelajaran bahasa Arab agar pembelajaran bahasa Arab sukses sesuai dengan tujuan yang telah dirumuskan.]

\section{DAFTAR RUJUKAN}

Abdul Wahab, Muhbib. Metode Penelitian dan Pembelajaran Nabwu: Studi Teori Linguistik Tammam Hassan. Jakarta: SPs UIN Syarif Hidayatullah Jakarta, 2008.

al-Khûlî, Muhammad 'Alî. Asâlîh Tadrîs al-Lughah al-'Arabiyyah, al-Mamlakah alArabiyyah al-Su'ûdiyyah: Maktabah al-Farzadaq, t.t.

al-'Anâtî, Walîd. Kitâb "Nûn wa al-Qalam” Dirâsab Lisâniyah Tarbawiyyah li Ta'lîm al'A rabiyyah li al-Nâthiqîn bi Ghairihâ, Jâmi'ah al-Batra, al-Urdun, 2009.

Ayatullah, "Penerapan Metode Eklektik pada Pembelajaran Bahasa Arab Siswa Kelas VI SDIT Anak Sholeh Mataram”, Jurnal Palapa, Vol. 4 No. 1, 2016

Budiono. Kamus Lengkap Bahasa Indonesia, Surabaya: Karya Agung, 2005.

Djaafar, Tengku Zahara. Kontribusi Strategi Pembelajaran Terhadap Hasil Belajar, Padang: Fakultas Ilmu Pendidikan Universitas Negeri Padang, 2001.

Ibrahim, Nurdin. "Hasil Belajar Siswa SLTP Terbuka Tanjung Sari Sumedang Jawa Barat", Jurnal Pendidikan dan Kebudayaan, No.031 Tahun ke-7 September, 2001.

Lundeto, Adri. Pengembangan Metode Pengajaran Bahasa Arab, http://jurnaliqro.files. wordpress .com/2008/08/04-adri-37-47.pdf, diunduh Rabu, 21 Oktober 2009.

M.F, Baradja. Kapita Selekta Pengajaran Bahasa, Malang : Penerbit IKIP Malang, 1990.

Parera, Jos Daniel. Linguistik Edukasional, Jakarta: Erlangga, 1987.

Peraturan Menteri Agama Republik Indonesia Nomor 2 Tahun 2008 Tentang Standar Kompetensi Lulusan Dan Standar Isi Pendidikan Agama Islam Dan Bahasa Arab Di Madrasah. Lembaran Negara Republik Indonesia Tahun 2008. Bab VI: Standar Kompetensi (SK) Dan Kompetensi Dasar (KD) Mata Pelajaran Pendidikan Agama Islam Dan Bahasa Arab Madrasah Ibtidaiyah.

Rahman, Anwar Abd. "Pengajaran Bahasa Arab dengan Metode Eklektik", Jurnal Adabiyah, Vol. 11 No. 1, 2011. 
Arabiyât Jurnal Pendidikan Bahasa Arab dan Kebahasaaraban, 5 (1), 2018

Rifa'i, Ahmad. "Implementasi Thariqah al-Intiqaiyyah ( Metode Eklektik ) Pada Pembelajaran Bahasa Arab di Mtsn Kediri 1", Jurnal Realita, Vol. 13 No. 2 Juli 2015.

Rivai, Veithzal. "Prestasi Hasil Belajar Peserta Program MM untuk Mata Kuliah Manajemen Keuangan", Jurnal Pendidikan dan Kebudayaan, No. 038 tahun ke-8 September, 2002.

Shaleh, Abdul Rahman. Muhbib Abdul Wahab. 2004. Psikologi Suatu Pengantar Dalam Persfektif Islam, Jakarta: Kencana. 2004.

Unsi, Baiq Tuhfatul. "Optimalisasi Pembelajaran Bahasa Arab Melalui Model Pembelajaran Komunikatif-Eklektik", Murobbi: Jurnal Ilmu Pendidikan, Vol. 1 No. 1, 2017. 